\title{
Peran Lembaga Sosial Kemasyarakatan dalam Pengelolaan dan Pemanfaatan Hutan
}

\author{
Dwi Setiawan Chaniago ${ }^{1}$, Anisa Puspa Rani, Solikatun \\ Universitas Mataram
}

\begin{abstract}
Social institutions are always an entity and are considered important in society. Social institutions have some important roles including maintaining and maintaining social value and also able to complement the needs of the community. With the existence of social institutions, it is expected to maintain a value that is considered important and able to be a tool and a container championing certain interests in society. The purpose of this research is to identify the role of social institutions in the village of Karang Bajo in the management and utilization of forests and to identify the pattern of relations between the social institutions of the village community is multilateral in support of forest management and utilization. This study uses qualitative approaches and sociological perspectives. Based on the results of the research known that the role of social society in the management and utilization of forest in the village of Karang Bajo divided into three forms of institutions, namely the first traditional pranata that play a role in preserving indigenous forests with various The rules that are sourced from the values of local wisdom, second, the institution of cultural and cultural tourism that plays a role in promoting the wisdom of local cultures, natural wealth and other village potentials in developing ecotourism areas, and third The honey bee cultivation institution, which contributes to the economical utilization of forest by also preserving the forest as a source of bee feed. The pattern of relationship between community social institutions in forest management and utilization is done by multiinstitutional synergy that is complementary and mutually supportive of each other. Relations between institutions are tied to solidarity values, economic systems, tradition systems, social control, and leadership.
\end{abstract}

Keywords : Roles, Social Institutions, Forest Utilization

\begin{abstract}
Abstrak
Lembaga sosial merupakan entitas yang selalu ada dan di anggap penting keberadaanya di dalam masyarakat. Lembaga sosial memiliki beberapa peranan penting diantaranya menjaga dan mempertahankan nilai sosial dan juga mampu melengkapi kebutuhan masyarakat. Dengan adanya lembaga sosial, diharapkan mampu mempertahankan nilai yang dianggap penting dan mampu menjadi alat dan wadah memperjuangkan kepentingan tertentu dalam masyarakat. Tujuan dari penelitian ini adalah untuk mengidentifikasi peran lembagalembaga sosial kemasyarakatan yang ada di Desa Karang Bajo dalam pengelolaan dan pemanfaatan hutan serta untuk mengidentifikasi pola hubungan antar-lembaga sosial masyarakat desa yang bersifat multilateral dalam menunjang pengelolaan dan pemanfaatan hutan. Penelitian ini menggunakan pendekatan kualitatif dan perspektif sosiologis. Berdasarkan hasil penelitian diketahui bahwa Peran lembaga sosial kemasyarakatan dalam pengelolaan dan pemanfaatan hutan di Desa Karang Bajo terbagi dalam tiga bentuk lembaga, yakni pertama pranata adat yang berperan dalam menjaga hutan adat dengan
\end{abstract}

\footnotetext{
${ }^{1}$ dwisetiawanchaniago@unram.ac.id
} 
berbagai aturan yang bersumber dari nilai-nilai kearifan lokal, kedua, lembaga penyelenggaran pariwisata adat dan budaya yang berperan dalam mempromosikan kearifan budaya lokal, kekayaan alam dan potensi desa lainnya dalam mengembangkan kawasan ekowisata, dan ketiga lembaga budidaya lebah madu, yang berperan dalam pemanfaatan ekonomis hutan dengan turut menjaga kelestarian hutan sebagai sumber pakan lebah. Pola hubungan antara lembaga sosial kemasyarakatan dalam pengelolaan dan pemanfaatan hutan dilakukan dengan sinergi multi-lembaga yang bersifat komplementer dan saling mendukung satu sama lain. Hubungan antar lembaga tersebut diikat dalam nilai-nilai solidaritas, sistem ekonomi, sistem tradisi, kontrol sosial, dan kepemimpinan.

Kata Kunci : Peran, Lembaga Sosial, Pemanfaatan Hutan

\section{Pendahuluan}

Lembaga sosial merupakan entitas yang sangat penting dalam kehidupan masyarakat. lembaga sosial tidak hanya berberfungsi untuk menjaga dan mempertahankan nilai sosial namun erat kaitanya dengan pencapaian berbagai kebutuhan masyarakat. Lembaga sosial adalah perwujudan kompleksitas normanorma dan kebiasaan-kebiasaan untuk mempertahankan nilai yang dianggap penting sekaligus wadah dan alat dalam memperjuangkan kepentingan tertentu di dalam masyarakat Dalam konteks pembangunan masyarakat perdesaan di Indonesia, hadirnya lembaga-lembaga formal pemerintah berimplikasi terhadap lembaga tradisional yang semakin kehilangan tempat berpijak (Rahardjo, 1999: 158).

Keberadaan lembaga tradisional yang berlandasakan hukum adat dan tradisi cenderung di posisikan secara antagonistik dengan lembaga-lembaga formal pemerintahan desa. Hal tersebut membawa implikasi lanjutan dimana aktor lembaga tradisional dan lembaga formal menjadi dualisme kepemimpinan dalam kehidupan masyarakat desa. Menurut Bachrein, karakteristik kelembagaan formal melalui penyelenggaraan pemerintah desa umumnya bersifat sederhana, tradisional, dan sentralistik pada elite pemerintah desa. Aparatur desa berada dalam posisi yang superior, Pembentukan lembaga Desa seperti BPD, LPM, PKK, Gapoktan, dan Lain sebagainya dijalankan tidak atas dasar kebutuhan masyarakat melainkan didasari pada pemenuhan ketentuan yang diatur perundangan. Pelaksanaan tugas dan fungsi kelembagaan oleh aparatur desa umumnya berorientasi pada pengalaman dan kebiasaan, dan cenderung tidak adaptif terhadap dinamika kebutuhan dan perkembangan masyarakat.

Karakteristik sistem kelembagaan tradisional menurut Soetomo memiliki kelebihan yakni mudah dalam mengorganisasi aktivitas bersama dalam berbagai tujuan. Hal tesebut disebabkan struktur sosial yang berorientasi pada ketokohan dan sikap invidualistik tidak lebih besar dari sikap kolektivitas masyarakat. Dalam pembangunan lembaga tradisional efektif dalam mengorganisir tindakan bersama, 
namun cenderung tidak efisien dari jika berkaitan dengan alokasi dan mobilisasi sumberdaya. Kondisi tersebut menjadi kelemahan yang terdapat dalam sistem kelembagaan tradisional. Untuk alasan tidak efisiennya kinerja, lembaga tradisional seringkali diabaikan dalam pembangunan di perdesaan.

Guna menunjang keberhasilan pembangunan masyarakat perdesaan, dualisme kelembagaan tersebut tidak bisa dipertahankan. Sebaliknya perlu upaya transformasi kelembagaan di perdesaaan dalam mendukung perubahan masyarakat. Persoalan dalam program kebijakan pemberdayaan masyarakat desa yang cenderung berjalan parsial dan tidak integratif perlu ditransformasi ke dalam pola hubungan kelembagaan yang bersifat multilateral. Hal tersebut berguna dalam meminimalisir dualisme dan ego-sektoral kelembagaan dalam pelaksanaan pembangunan perdesaan yang selama ini tidak efektif dan efisien. Adapun tujuan penelitian ini adalah untuk mengidentifikasi peran lembaga-lembaga sosial masyarakat yang ada di Desa Karang Bajo dalam pengelolaan dan pemanfaatan hutan dan mengetahui pola hubungan antar-lembaga sosial masyarakat desa yang bersifat multilateral dalam menunjang pengelolaan dan pemanfaatan hutan.

\section{Kerangka Analisis}

Lembaga sosial menurut Horton dan Hunt (1999) merupakan sistem norma untuk mencapai suatu tujuan atau kegiatan yang oleh masyarakat dianggap penting. Lembaga sosial merupakan manifestasi dari tata kelakuan masyarakat yang terinstitusionalisasi dalam mencapai tujuan atau kepentingan tertentu. Oleh karena itu, lembaga sosial tidak bersifat statis. Lembaga sosial berubah dan berkembang seiring dengan perubahan yang terjadi di dalam masyarakat. Oleh karena fungsi lembaga sosial berkaitan dengan pemenuhan kebutuhan masyarakat, maka dinamika lembaga sosial ditentukan proses dan perubahan yang terjadi (Rahardjo, 1999).

Lembaga sosial terbentuk melalui proses habitualisasi (pembiasaan) dalam melakukan kegiatan untuk mencapai tujuan tertentu. Oleh karena itu, lembaga sosial sangat terkait dengan sistem solidaritas yang menjadi penentu ikatan-ikatan sosial dalam masyarakat. Berdasarkan bentuk solidaritas, Durkheim membagi masyarakat ke dalam dua bentuk yakni masyarakat solidaritas mekanik dan masyarakat solidaritas organik. Kedua tipe masyarakat berdasarkan tipe solidaritas tersebut berbeda dalam berbagai indikator aspek sistem sosial yang meliputi solidaritas, sistem ekonomi, kontrol sosial, tipe kepemimpinan, respon terhadap perubahan, serta orientasi masa depan.

Masyarakat dalam tipe solidaritas mekanik memiliki kohesivitas sosial yang tinggi. Komponen masyarakat cenderung memiliki kolektifitas yang tinggi yang diikat oleh komitmen moral sesuai dengan sistem nilai tradisional yang dianut. Umumnya masyarakat tip solidaritas mekanik ditandai dengan bentuk masyarakat yang homogen, dan tidak bersifat individualistic, dan mengedepankan nilai-nilai 
kolektif bersama dalam mencapai kepentingan atau tujuan tertentu. Dalam proses pembangunan masyarakat dengan tipe solidaritas mekanik umumnya dalam kelembagaan sosialnya memiliki kelebihan yakni lebih mudah untuk mengorganisasi aktivitas dalam kehidupan bersama. Tindakan bersama akan mendapat dukungan anggota masyarakat selama berpegang teguh pada sistem nilai dan norma. Kendati demikian, memiliki kelemahan yakni tidak selalu efisien dalam alokasi dan mobilisasi sumberdaya dalam pembangunan.

Masyarakat dengan tipe solidaritas organik cenderung memiliki kohesifitas yang rendah dibanding pada tipe solidaritas mekanik. Hal tersebut disebabkan sikap individualistik, serta terorganisirnya masyarakat dalam spesialisasi kerja yang beragam. Spesialisasi dalam hubungan kerja tersebut menjadi dasar bagi terciptanya integrasi masyarakat. Dalam pembangunan, masyarakat dengan karakteristik ini dalam kelembagaan cenderung memiliki kelebihan yakni rasional, terbuka terhadap perubahan, cenderung lebih efisien dalam memanfaatkan sumber daya di banding pada masyarakat dengan tipe solidaritas mekanik. Namun terdapat pula kekurangan yakni sulitnya mengorganisir anggota masyarakat yang berbeda dalam pembangunan, karena tipe ini telah mengenal spesialisasi dan pembagian kerja yang baik.

Jika ditarik dalam fenomena pembangunan di perdesaan, tentunya dua tipologi masyarakat tersebut harus diakomodir dan difasilitasi dalam upaya optimalisasi dan partisipasi dalam pembangunan. Proses tersebut hanya akan terjadi jika lembaga-lembaga sosial masyarakat desa didorong untuk bertransformasi. Transformasi tersebut yakni upaya-upaya pendayagunaan lembaga sosial masyarkat yang telah ada, namun mekanisme prosesnya diintervensi agar lebih adaptif dan terintegrasi dalam kerangka multilateral dalam mengimbangi dinamika perkembangan masyarakat yang kompleks. Transformasi tersebut diarahkan pula pada perbaikan-perbaikan sistem perananan dalam kelembagaan seperti, aktor, sistem dan mekanisme peran, serta sistem norma baru dalam upaya mendorong perubahan yang terencana dalam wadah kelembagaan. Adapun wahana kelembagaan yang dimaksud adalah Balai Rakyat sebagai tempat untuk meningkatan peran serta masyarakat yang mandiri dan adaptif dalam meningkatkan akses terhadap layanan sosial dasar serta mewujudkan kesejahteraan secara berkelanjutan. Untuk lebih jelasnya, kerangka konseptual penelitian ini, sebagaimana termuat dalam skema berikut ini: 
Skema Kerangka Konseptual

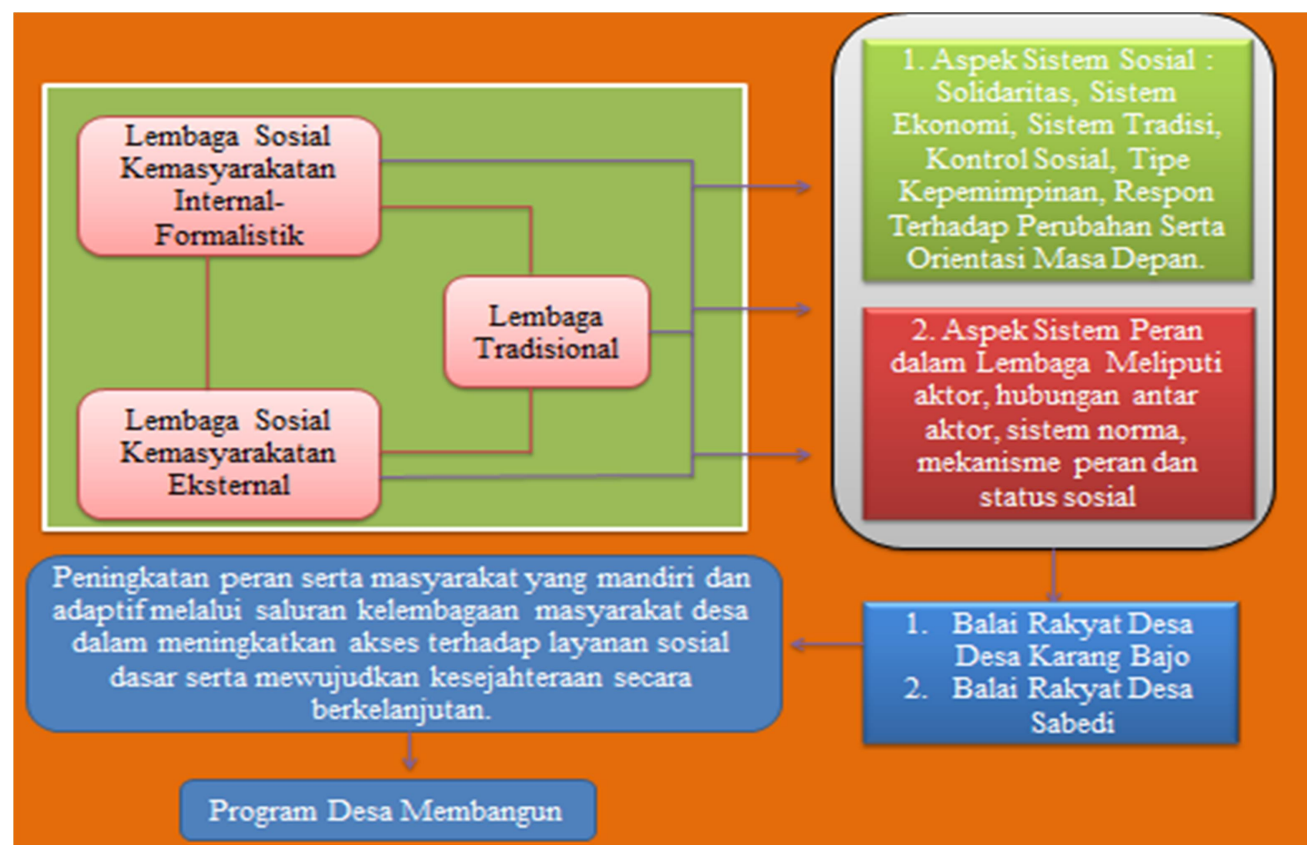

\section{Metode Penelitian}

Lokasi penelitian ini berada di Desa Karang Bajo, Kecamatan Bayan, Kabupaten Lombok Utara, Provinsi Nusa Tenggara Barat. Penelitian ini menggunakan metode penelitian kualitatif eksploratif . Pada tahap awal peneliti akan mengumpulkan informasi seputar deskripsi umum tentang peran lembagalembaga sosial masyarakat yang ada di Desa Karang Bajo, dalam pengelolaan dan pemanfaatan hutan. Stelah itu dilanjutkan dengan penelusuran informasi deskriptif tentang peran pola hubungan antar-lembaga sosial dengan masyarakat Desa Karang Bajo dalam pengelolaan dan pemanfaatan hutan. Melalui metode tersebut diharapkan peneliti mendapat pemahaman mendalam terkait pemahaman subyektif masyarakat desa dalam memanfaatkan dan mengelola hutan.

\section{Peran Lembaga Sosial Kemasyarakatan Dalam Pengelolaan dan Pemanfaatan Hutan}

Dalam upaya mengimpelementasikan kebijakan social forestry yang mendorong masyarakat di sekitar kawasan memiliki kapasitas dalam memanfaatkan dan mengelola hutan secara seimbang dan berkelanjutan baik secara ekonomi, ekologis, sosial dan budaya, dipandang perlu ada kesepahaman (konsensus) diantara 
berbagai unsur masyarakat. Pengelolaan dan pemanfaatan hutan harus berbasis pemberdayaan masyarakat dengan meningkatkan kesadaran dan peran aktif masyarakat untuk bisa merasa memiliki hingga mau menjaga dan merawat hutan. Pemberdayaan tersebut haruslah pula dapat membawa manfaat pada kesejahteraan masyarakat dengan turut mempertimbangkan daya dukung ekologis,serta kelestarian ekosistem flora dan fauna di kawasan hutan.

Guna mencapai tujuan tersebut, pengelolaan dan pemanfaatan hutan perlu direorientasi menuju pola pemanfaatan secara kolektif dalam wahana kelembagaan yang menggantikan pola lama pemanfaatan hutan secara individual. Hal tersebut disamping bertujuan untuk mendorong proses pemberdayaan masyarakat di sekitar kawasan, juga bermanfaat dalam mempermudah kegiatan pengawasan dan kontrol dalam pengelolaan dan pemanfaatan hutan dengan pendekatan institusional yang mengikat anggota masyarakat. Selain itu, pemanfaatan hutan harusnya diarahkan pada pemanfaatan hutan hasil hutan bukan kayu, pemanfaatan jasa lingkungan maupun pemanfaatan areal hutan sebagai kawasan wisata. Prinsipnya hutan harus bisa mendatangkan manfaat bagi masyarakat namun disaat bersamaan ketika masyarakat di sekitar kawasan memperoleh manfaat dari keberadaan hutan, dapat tercipta hubungan mutual benefit dengan ekologi hutan.

Corak pengelolaan dan pemanfaatan dalam social forestry bertujuan mengakomodir kebutuhan masyarakat di sekitar kawasan. Berbicara tentang kawasan hutan di Kabupaten Lombok Utara pada umumnya tersimpan banyak potensi hutan yang dapat dimanfaatkan sebagai sumber penghasilan masyarakat. Keindahan alam dan ekologi hutan, potensi pemanfaatan hasil hutan bukan kayu (HHBK) khususnya budidaya lebah, serta keberadaan sumber mata air yang semuanya sangat bergantung dengan kelestarian hutan. Untuk menjaga agar hutan tetap lestari dan di sisi lain dapat memberikan manfaat ekonomis, maka diperlukan peran serta lembaga kemasyarakatan yang secara sinergis dalam mengelola dan memanfaatkan hutan.

Pendekatan pengelolaan dan pemanfaatan hutan berkarakter social forestry pada dasarnya merupakan upaya mengakomodir hak-hak masyarakat baik berupa lembaga sosial kemasyarakatan dan lembaga adat dalam upaya pengelolaan kawasan hutan guna meningkatkan kesejahteraan masyarakat sekaligus berperan aktif dalam pelestarian lingkungan. Lembaga sosial kemasyarakatan yang berkenaan dengan pengelolaan dan pemanfaatan hutan di Desa Karang Bajo, terdiri atas lembaga sosial kemasyarakatan, dan lembaga pranata adat. Tujuan dari adanya social forestry adalah terciptanyaa pengelolaan dan pemanfaatan kawasan hutan yang berbasis pemberdayaan dan peningkatan kesejahteraan masyarakat serta kelestarian ekologis hutan.

Pada prinsipnya pemanfaatan hutan perlu mengintegrasikan peningkatan ekonomi dan kesejahteraan masyarakat dengan usaha menjaga kelestarian hutan. Di 
Desa Karang Bajo, upaya pengelolaan dan pemanfaatan hutan terdiri atas beberapa unsur yakni pranata adat, kelompok budidaya lebah, serta kelompok sosial kemasyarakatan penyelenggara pariwisata adat dan budaya. Terdapat tiga bentuk lembaga sosial kemasyarakatan yang berperan aktif dalam pengelolaan dan pemanfaatan social forestry di Desa Karang Bajo. Ketiga bentuk lembaga sosial kemasyarakatan tersebut bergerak dalam bidang yang berbeda-beda namun saling bersinergi dalam pelaksanaan peran masing-masing dalam mengelola dan memanfaatkan hutan.

Pranata adat merupakan salah satu elemen penting pada masyarakat Bayan pada umumnya yang berperan dalam merawat dan menjaga hutan. Pranata adat merupakan kelompok pemimpin adat yang dipercaya dan mengemban tugas dalam menjaga kelestarian hutan sebagai bagian dari menjaga eksistensi lingkungan hidup dan manusia yang saling berkaitan. Peran pranata adat merupakan representasi dari kearifan lokal masyarakat adat dalam menjaga keseimbangan hubungan antara manusia dan alam yang saling menopang satu sama lain.

Peran serta komunitas adat yang secara turun temurun menjaga dan melindungi hutan. Upaya menjaga dan melindungi hutan tersebut hadir melalui berbagai bentuk kearifan lokal yang termanifestasi dalam berbagai ritual adat, larangan dan sanksi yang mengatur pengelolaan hutan agar tetap terjaga. Pranata adat tersebut tidak hanya berperan pada hutan yang terdapat di wilayah administrative Desa Karang Bajo, namun juga secara umum di daerah Bayan. Dipergunakannya sistem kearifan lokal tersebut secara komunal menggambarkan pengakuan masyarakat dan beberapa desa lainnya terhadap eksistensi pranata adat dalam menjaga kelestarian hutan.

Aturan yang terdapat dalam lembaga adat ini sangat ketat, dan tidak boleh dilanggar oleh masyarakat, karena memiliki sanksi yang cukup berat. Lembaga adat ini berfungsi hanya sebatas untuk memlihara dan menjaga daerah atau wilayah hutan yang termasuk dalam kawasan adat, yang tidak boleh di rusak ataupun diganggu gugat. sistem sanksi yang diberlakukan oleh lembaga adat. Dengan kata lain, wilayah hutan yang ada di Desa Karang Bajo, merupakan salah stau hutan yang sangat disakralkan oleh masyrakat setempat. Bahkan masyarakat tidak boleh memanfaatkan hasil alam atau hutan tersebut untuk mencari keuntungan pribadi atau penghasilan. Hal ini dapat kita lihat dari banyaknya ritual adat yang dilakukan oleh para pemangku adat sebagai ritual untuk menjaga kelestarian hutan dan untuk memohon hujan. Nama pemangku adat yang bertugas utnuk menjaga hutan biasanya disebut dengan "perumba daya"

Peraturan yang ada dalam lembaga adat adat ini juga terdapat di dalam peraturan desa, dengan berbagai aturan dan sanksi yang akan diberlakukan jika masyarakat melanggar aturan tersebut. Salah satu aturan tersebut mengatakan bahwa "barangsiapa diketahui merusak hingga menebang pohon di dalam hutan 
yang masuk dalam wilayah kekuasaan adat, maka kan diberikan sanksi untuk mengeluarkan atau membeli satu ekor kerbau lengap dengan beras, dan bumbubumbunya.

Lembaga adat yang bertugas untuk mengawasi pengelolaan hutan juga tedapat di berbagai wilayah di Kecamatan Bayan, tetapi khusus untuk daerah Karang Bajo sendiri, lembaga adatnya juga fokus untuk menjaga pemanfaatan dan pemeliharan sumber mata air yang ada di sekitar wilayah hutan adat tersebut, yang penggunaannya untuk seluruh masyrakat yang ada di empat desa di Kecamatan Bayan itu sendiri.

Peran komunitas adat pada umumnya banyak berfokus pada upaya-upaya merawat hutan agar tetap lestari. Kendati tidak sampai pada upaya optimalisasi pemanfaatan hutan secara ekonomis, namun potensi kearifan lokal pranata adat turut diakomodir oleh kelompok penyelenggara pariwisata adat dan budaya. Dalam hal ini, kearifan lokal pranata adat dilihat sebagai potensi lokal yang bernilai secara kultural dan di sisi lain memiliki nilai ekonomis jika dikemas dengan sebagai daya tarik pariwisata.

Keberadaan pranata adat dan sistem pemeliharaan hutaan tidak hanya berdampak pada kelestarian hutan. Saat ini, kelestarian ekosistem hutan selain bermanfaat sebagai potensi pariwisata juga telah membawa manfaat ekonomis dengan tumbuhnya usaha budidaya lebah yang terorganisir dalam kelompok budidaya di kampung lebah Karang Bajo.

Kelompok budidaya lebah merupakan salah satu pemanfaat hutan yang merasakan manfaat adanya pengaturan pranata adat dalam menjaga hutan. Usaha budidaya lebah yang bergantung dengan ketersediaan akan pakan lebah yang hanya akan didapat jika kondisi hutan lestari. Apa lagi jika dilihat secara kelembagaan, kelompok ini representatif dalam upaya menjaga kelestarian hutan Gunung Sasak. Nilai ekonomis madu sebagai hasil hutan bukan kayu, serta kebutuhan pakan yang didapat melalui kelestarian lingkungan menjadi dasar bagi upaya pemanfaatan hutan yang mengutamakan keselarasan fungsi ekonomis dan ekologis kawasan bagi di Desa Karang Bajo.

Jika dilihat dari tiga unsur lembaga sosial kemasyarakatan yang ada di Desa Karang Bajo, berdasarkan dinamika pengelolaan dan pemanfaatan kawasan hutan, terdapat kecenderungan potensi ekonomi yang besar bagi masyarakat Desa Karang Bajo. Ketiga unsur yang berkaitan dalam pengelolaan dan pemanfaatan hutan tersebut dapat disinergikan secara optimal melalui kegiatan social learning process pengembangan kelembagaan berbasis komunitas sebagai pengelola dan pemanfaat hutan dalam peningkatan ekonomi dan pemeliharaan ekosistem hutan berbasis hasil hutan bukan kayu, yakni melalui usaha budidaya lebah, pengembangan pariwisata dan lain sebagainya. 
Kebijakan social forestry tidak hanya berfokus pada fasilitasi pengelolaan dan pemanfaatan hutan. Lebih jauh, perlu upaya-upaya pemberdayaan yang bersifat teknis terhadap masyarakat di sekitar kawasan untuk dapat mengelola dan memanfaatkan hutan sesuai prinsip kelestarian ekologis dan manfaat ekonomis. Pemberdayaan tersebut diperlukan untuk mewujudkan tata kelola pemanfaatan hutan yang baik, bertanggungjawab, dan berkelanjutan. Langkah awal yang dapat dilakukan yakni meningkatkan parsitipasi masyarakat umum agar mau bergabung dalam berbgai kegiatan lembaga sosial kemasyarakatan yang ada. Hal tersebut berguna dalam membangun pemahaman teknis tentang rehabilitasi hutan, , budidaya, pemanfaatan hasil hutan bukan kayu, serta penguatan pemasaran dalam memperoleh manfaat ekonomis hutan.

Upaya optimalisasi pengelolaan dan pemanfaatan hutan secara kelembagaan dapat dilakukan melalui jalur pemberdayaan. Pendekatan pemberdayaan yang dimaksud adalah penguatan lembaga sosial kemasyarakatan yang ada dalam pemanfaatan hutan dengan sasaran transformasi perilaku masyarakat dalam memanfaatkan hutan. Mellui berbagai sarana lembaga sosial kemasyarakat yang ada, diharapkan daoat merubah mindset masyarakat umum dalam memahami pengelolaan dan pemanfaatan hutan. Melalui model pemberdayaan lembaga masyarakat lokal dapat ditanamkan seperangkat nilai, tata aturan pengetahuan hingga keterampilan yang relevan dalam upaya pengelolaan dan pemanfaatan hutan secara ekonomis serta lestari secara ekologis. Dalam model pemberdayaan berbasis lembaga lokal tersebut, tentu penting memposisikan masyarakat tidak sebagai penyebab masalah, melainkan bagian dari potensi penyelesaian masalah.

Motif ekonomi dan kelestarian ekologis dalam pemanfaatan sumberdaya hutan tentu menjadi perhatian utama. Hal tersebut selaras dengan tujuan pemanfaatan social forestry dalam mensejahterakan masyarakat di sekitar kawasan hutan. Hanya saja prinsip keberlanjutan harus ditanamkan pada masyarakat. Agar hutan bisa menjadi sumber pendapatan keluarga, maka kelestarian hutan perlu dijaga. Untuk itu, upaya pemanfaatan perlu didorong ke pemanfaatan hasil hutan bukan kayu. Upaya reorientasi perilaku masyarakat tentu bukan usaha mudah. Namun dengan melihat potensi kelembagaan sosial masyarakat yang ada di Desa Karang bajo, peluang untuk merubah perilaku masyarakat di sekitar kawasan sangat terbuka lebar untuk dilakukan.

Social Forestry $\mathrm{HKm}$ pada dasarnya merupakan bentuk kebijakan pemerintah berkarakter pemberdayaan dalam mengubah perilaku individu. Social Forestry merupakan salah satu cara pemerintah dalam membuka ruang partisipasi bagi masyarakat. Status masyarakat sebagai pemanfaat hutan merupakan bentuk penyerahan hak kelola bagi masyarakat dalam mengelola dan memanfaatkan hutan. Distribusi peran dari pemerintah kepada kelompok masyarakat perlu dilakukan 
dalam wahana kelembagaan yang membentuk agensi-agensi yang menjalankan kegiatan pemeliharaan, pengelolaan, dan pemanfaatan hutan. Pendekatan kelembagaan tentu tidak hanya sebatas upaya menumbuhkan wahana kelembagaan. lebih jauh, lembaga kemasyarakatan dalam pemanfaatan hutan perlu memiliki instrument yang terukur dalam merubah perilaku dan kebiasaan masyarakat dalam memanfaatkan hutan.

Intervensi perubahan perilaku pemanfaatan hutan menggunakan pendekatan pemberdayaan melalui lembaga sosial kemasyarakatan dapat dilakukan dalam tiga aspek, yakni pertama lembaga sosial kemasyarakatan sebagai wahana peningkatan pengetahuan dan kesadaran masyarakat untuk dapat memanfaatkan hutan secara berkelanjutan baik secara ekologis maupun ekonomis. Wujudnya berupa edukasi jenis tanaman yang diperbolehkan ditanam di kawasan HKm, pemanfaatan jenis hasil hutan bukan kayu (HHBK), pengolahan produk HHBK, pengembangan kapasitas keorganisasian anggota, edukasi dan sosialisasi proses reforestasi, pengembangan pariwisata hutan dan peningkatan sektor layanan jasa lingkungan serta pemilihan jenis tanaman yang bisa dipergunakan sebagai sumber pakan untuk usaha budidaya lebah madu.

Kedua, Kelompok sosial kemasyarakatan yang ada di Desa Karang Bajo potensial menjadi wahana kelembagaan dalam peningkatan keterampilan masyarakat dalam memanfaatkan hasil hutan bukan kayu, yakni melalui budidaya lebah madu berbagai produk olahan madu, peningkatan keterampilan pemasaran produk, mengembangkan budidaya lebah trigona (selain apis dorsata), peningkatan keterampilan dalam memelihara dan merehabilitasi hutan, serta upaya lainnya yang berguna dalam meningkatkan pemanfaatan hutan baik secara ekonomis maupun secara ekologis. Serta upaya peningkatan integrasi wisata alam dan budaya yang berbasis kearifan budaya lokal masyarakat Bayan.

Ketiga, Kelompok sosial kemasyarakatan yang ada di Desa Karang Bajo potensial dalam membentuk perilaku dan kebiasaan masyarakat melalui pengelolaan dan pemanfaatan hutan secara kelembagaan. Terbentuknya kebiasaan pemanfaatan hutan secara bertanggungjawab dengan memperhatikan keseimbangan ekosistem, serta pemanfaatan HHBK (budidaya lebah madu) sebagai upaya peningkatan pendapatan keluarga yang sejalan dengan upaya melestarikan ekologi hutan.

Optimalisasi pemanfaatan hutan berbasis lembaga sosial kemasyarakatan diperlukan dalam membangun kolektivitas masyarakat dalam menjaga kelestarian hutan sekaligus dapat memperoleh manfaat ekonomis dari hutan. Berdasarkan lembaga sosial kemasyarakat yang ada di Desa Karang Bajo kolektivitas dalam pengelolaan dan pemanfaatan huta, khususnya yang berkaitan dengan pengembangan potensi pariwisata hutan dan budidaya lebah telah terbentuk. Hanya saja untuk dapat menjadikan lembaga sosial kemasyarakatan tersebut optimal 
diperlukan intervensi pada tiga fokus aspek yang meliputi pengembangan infrastruktur, peningkatan kapasitas, serta pemantapan aspek jaringan ekonomi pariwisata hutan dan budidaya lebah.

Pengembangan infrastruktur dalam pengembangan lembaga sosial kemasyarakatan meliputi dua komponen utama, yakni infrastruktur yang berkaitan dengan pengelolaan pariwisata hutan, dan infrastruktur pengembangan usaha budidaya lebah madu, serta fasilitasi berbagai sarana dan prasarana ritual dan adat istiadat lokal. Infrastruktur pengelolaan hutan berguna dalam memfasilitasi saranaprasarana bagi masyarakat dalam menjaga dan merawat hutan. Dalam hal ini, pendekatan pemberdayan sangat diperlukan agar atensi masyarakat dalam merawat dan menjaga hutan bisa optimal..

Pengembangan infrastruktur usaha budidaya lebah madu perlu ditingkatkan. Faktor infrastruktur yang selama ini telah diupayakan secara swadaya oleh Kelompok Madu Sari perlu diperkuat dengan berbagai bantuan pemerintah. Dukungan sarana prasarana berupa Setup, kloni lebah, peralatan peyaringan dan pengemasan madu sangat diperlukan. Upaya budidaya lebah madu perlu disertai dengan efektifitas pemanfaatan madu dengan pengembangan diversifikasi produk. Hanya saja untuk upaya diversifikasi produk madu tersebut masih terkendala kurangnya infrastruktur usaha. Diversifikasi produk yang belum bisa dikembangkan secara optimal jika tidak ditunjang sarana dan prasarana yang memadai.

Upaya mendorong berkembangnya lembaga sosial kemasyarakatan di Desa Karang Bajo perlu ditopang peningkatan kapasitas. Terdapat dua aspek penting kapasitas perlu dikembangkan yakni pengembangan kapasitas personal anggota kelembagaan, serta pengembangan kapasitas komunitas sebagai basis pengembangan modal sosial dan membangun kolektifitas dalam pengelolaan dan pemanfaatan hutan. Pendekatan dalam peningkatan kapasitas tersebut dapat dilakukan dengan intervensi pemberdayaan yang bersifat partisipatif.

Intervensi pengembangan kapasitas sangat potensial untuk dilakukan mengingat potensi lembaga sosial kemasyarakatan telah ada dan momitmen anggota kelompok dalam menjaga memeliharan kelestarian hutan telah ada. Umumnya anggota memiliki pemahaman atas konsekwensi rusaknya hutan terhadap keseimbangan kelestarian alam, moralitas terhadap alam serta aktivitas ekonomi budidaya lebah. Kelestarian lingkungan merupakan kebutuhan bagi semua pihak. Untuk menjamin keseimbangan ekosistem hutan, pranata adat menerapkan sanksi yang tegas untuk meminimalisir aktifitas perusakan hutan. Anggota masyarakat yang melanggar konsensus bersama akan dikenai sanksi sosial.

Bidang intervensi ketiga dalam mendukung pengelolaan dan pemanfaatan kawasan oleh lembaga sosial kemasyarakatan agar membawa dampak ekonomis terhadap kesejahteraan masyarakat di sekitar kawasan adalah pemantapan aspek jaringan ekonomi, baik dari pengembangan sektor pariwisata maupun budidaya 
lebah madu. Optimalisasi jaringan ekonomi berguna untuk maksimalisasi manfat ekonomi bagi masyarakat. jika dampak ekonomi dapat maksimal maka tingkat ketertarikan masyarakat untuk turut serta dlam mengelola dan memanfaatkan hutan secara bijak menjadi lebih baik. Dalam kondisi yang demikian, maka upaya membentuk kesadaran dan pengetahuan masyarakat secara massif lebih mudah. Aspek kemanfaatan hutan harus terbentuk dalam dua bentuk mulai dari jangka pendek seperti manfaat melalui budidaya lebah madu, manfaat di sektor pariwisata dan lain sebagainya, sedangkan manfaat jangka panjang dari pemanfaatan hutan yakni kelestarian hutan dalam kaitannya dengan daya dukung alam seperti meminimalisir bencana dan lain sebagainya.

Khususnya bagi lembaga sosial kemasyarakatan yang bergerak di bidang budidaya lebah diperlukan upaya pemantapan jaringan ekonomi baik dari segi permodalan dan pemasaran komoditas perlu dikembangkan. intervensi pengembangan jaringan permodalan perlu dilakukan untuk memperkuat modal dan memperbesar skala usaha. Selama ini dalam usaha budidadaya lebah madu distimulus akses permodalan baik dari sumber permodalan desa maupun akses ke bank. Upaya tersebut dapat pula diarahkan agar usaha yang dijalankan dapat memenuhi prayarat akses modal di perbankan (bankable). Selain itu, lembaga keuangan makro Badan Usaha Milik Desa berupa Usaha Ekonomi Desa-Simpan Pinjam (UED-SP) juga merupakan potensi dalam permodalan.

Pengembangan jaringan pemasaran juga perlu mendapatkan intervensi pemerintah maupun stakeholder lain. Model pemasaran yang dijalankan kelompok budidaya lebah dapat dioptimalkan melalui sinergi dengan kelompok pengelola pariwisata yang ada agar dapat menjadi mitra dan media pemasaran yang efektif dan efisien. Selain itu upaya pemasaran melalui media online dan jaringan pemasaran lainnya perlu dipertimbangkan, kendati demikian, ekspansi pemasaran juga harus diimbangi dengan kemampuan dalam mengahasilkan produk agar marketable. Dalam usaha budidaya lebah hal tersebut tentunya sangat bergantung pada kondisi ketersediaan pakan. Hal tersebut tentu hanya akan tercapai jika daya dukung lingkungan alam yang menyediakan pakan lebah dapat terjaga dengan baik.

\section{Pola Hubungan Antar Lembaga Sosial Kemasyarakatan Dalam Pengelolaan dan Pemanfaatan Hutan}

Sebagaimana yang telah diungkapkan sebelumnya bahwa upaya pengelolaan dan pemanfaatan hutan di Desa Karang Bajo melibatkan lembaga sosial kemasyarakatan yang terdiri atas pranata adat, penyelengara pariwisata adat dan budaya, serta usaha udidaya lebah madu. Tiap lembaga sosial kemasyarakatan tersebut memiliki karakteristik pendekatan yang berbeda namun dalam melaksanakan perannya berjalan saling melengkapi satu sama lain. Pengelolaan dan pemanfaatan hutan yang dilakukan oleh pranata adat, mengandalkan nilai 
tradisional dan kearifan lokal. Dalam hal keanggotaan juga ditetapkan berdasarkan keturunan yang pada dasarnya semua dikembalikan pada sistem kepercayaan yang berlaku di dalam adat. Pada kelompok PPAB dari segi keanggotaan misalnya lebih bersifat inklusif dengan mencoba menjembatai berbagai kebutuhan dan peluang pariwisata yang dapat dikembangkan dengan memanfaatkan potensi kekayaan kearifan lokal, budaya dan alam. Inklusifitas lembaga PPAB juga dilakukan melalui berbagai hubungan kerja sama dengan pihak terkait untuk mengembangkan daerah eko wisata di wilayah hutan adat Karang Bajo. Sedangkan lembaga sosial kemasyarakat yang bergerak dibidang budidaya lebah lebih berfokus pada pemanfaatan hasil huta bukan kayu sebagai sumber pemasukan ekonomi. dari jenis lembaga sosial kemasyarakatan tersebut, saling bersifat komplementer peran dan mengelola dan memanfaatkan hutan.

Keberadaan lembaga-lembaga tersebut baik yang formal maupun informal dirasakan sudah cukup membantu masyarakat setempat. Terutama dengan keberadaan lembaga informal yang membantu mengembangkan dan mempromosikan kawasan hutan wisata yang di lindungi dan membawa dampak positif bagi masyarakat setempat untuk mengetahui pola hubungan lembaga sosial kemasyarakatan dalam mengelola dan memanfaatkan hutan maka dapat dilihat pada jabaran berikut ini:

\section{Solidaritas}

Untuk solidaritas masyarakat setempat masing sangat kuat, baik antara masyarakat dalam kelompok yang satu dengan kelompok yang lain, hal ini dapat dilihat dari kerja sama masyarakat dalam menjaga dan kawasan hutan adat yang sangat dilindungi. Solidaritas yang kuat ditunjukkan dengan saling membantu sama lain dalam melakukan pengawasan dan pengelolaan terhadap kawasan hutan adat tersebut.

Kerja sama yang dilakukan oleh masyarakat setempat dalam menjaga kelestarian hutan tersebut membawa manfaat, seperti misalnya menjadikan kawasan hutan tersebut menjadi kawasan wisata. Meskipun pendapatannya tidak secara langsung didapatkan oleh masyarakat. Tapi tentu dengan kerja sama mereka ini mereka bisa sama-sama berkontribusi dalam membangun daerah dan desa mereka. Dengan ciri khas yang masih memegang teguh adat-istiadat dan pelaksanaan ritual yang masih dijalankan hingga saat ini menjadi point tambahan tersendiri bagi masyarakat setempat yang daerahnya saat ini menjadi daerah wisata.

Selain itu, sistem gotong royong yang ada dalam masyarakat juga masih terjaga hingga saat ini, hal ini bisa dilihat dari kerja sama masyarakat saat membersihkan dan menangani masalah kebakaran hutan yang sempat terjadi di daerah tersebut, yang berasal dari salah satu kebun warga. Masyarakat kemudian saling bergotong royong utnuk membersihkan lahan tersebut, mulai dari 
mamadamkan api, hingga membersihkan lahan kering sisa kebakaran hutan, agar tidak merusak kawasan hutan adat yang sama-sama mereka lindungi.

Permasalahan-permasalahan seperti ini seringkali masih banyak terjadi di masyarakat, terutama masih ada masyarakat yang berani menebang pohon di dalam kawasan hutan yang dilindungi. Permasalahan seperti ini biasanya diselesaikan secara bersama-sama baik dengan masyrakat maupun lembaga-lembaga yang terlibat di dalamnya. Hal ini dilakuakn utnuk etrus menanmkan kesdaran bagi amsyarakat setempat bahwa penjagaan dan pemanfaatn kawasan hutan tetap menjadi tanggung jawab setiap kelompok masyarakat. Sehingga kegiatan seperti ini masih etrus dilakukan hingga saat ini.

\section{Sistem ekonomi}

Saat ini aktivitas ekonomi sebagian masyarakat adalah pertanian dan perkebunan, akan tetapi hal yang paling penting adalah bahwa seluruh aktivitas ekonomi yang dilakukan oleh masyarakat setempat sama sekali tidak berhubungan secara langsung dengan pemanfaatan hutan yang ada di Desa Karang Bajo. Karena seperti yang dijelaskan sebelumnya bahwa kawasan hutan yang ada tersebut, merupakan kawasan hutan adat yang sangat disakralkan oleh masyarakat sehingga sangat dilindungi oleh lembaga adat dan masyarakat setempat.

Salah satu usaha atau aktivitas ekonomi yang sedang dikembangkan masyarakat setempat saat ini adalah kampung ternak lebah. Aktivitas tersebut dilakukan dan dikembangkan oleh masyarakat di dalam kebun milik sendiri, bukan di dalam kawasan hutan adat yang dilindungi. Dan hampir sebagai kebun milik warga tersebut banyak yang berbatasan dengan kawasan hutan adat. Dan jika masyarakat ingin memanen hasil ternak lebah yang berbatasan dengan kawasan hutan adat, masih diperbolehkan, selama tidak merusak kawasan hutan adat tersebut. Namun satu hal yang pasti, komitmen pelaksanaan hukum adat yang berdampak pada kelestarian hutan turut menopang aktivitas budidaya lebah. Hal tersebut disebabkan tersedianya pakan lebah melalui hutan adat yang terjaga.

Hal ini karena di dalam kawasan hutan etrsebut merupakan lokasi yang dianggap sakral karena adanya peninggalan dan situs sejarah yang dianggap sakral oleh masyarakat setempat. Sehingga saat ini kawasan hutan adat seringkali dijadikan sebagai tempat untuk melakukan ritual khusus, salah staunya ritual utnuk meminta hujan, dan memohon perlindungan bagi masyarakat setempat dan kelestarian hutan tersebut. Nilai itulah yang kemudian menjadaikan kawasan hutan adat sebagai hutan wisata yang dilindungi baik oleh pemerintah setempat hingga lembaga adat yang ada di Karang Bajo tersebut. Sehingga masyarakat dilarang untuk merusak ataupun menebang atau melakukan aktivitas ekonomi lainnya yang berkaitan dengan pemanfaatan hutan tersebut. 
Salah satu aktivitas ekonomi lainnya yang juga dikembangkan adalah pengembangan kawasan hutan wisata. Hal tersebut sebagaimana dimotori oleh PPAB yang berusaha mengintegrasikan potensi alam yang ada di Kabupaten Lombok Utara secara umum maupun Desa Karang Bajo secara khusus dalam upaya meningkatkan masyarakat setempat. Selain itu kelompok PPAB juga berkomitmen secara sinergis dalam memasarkan produk budidaya lebah kepada wisatawan sehingga dalam aktivitas ekonomi yang terbangun secara komplementer.

\section{Sistem tradisi}

Jenis tradisi yang masih dipegang teguh oleh masyarakat adalah tradisi pelaksanaan ritual-ritual adat tertentu yang dilakukan oleh kelompok masyarakat, ketika memohon untuk diturunkannya hujan dan doa-doa untuk menjaga keselamatan warga setempat dan untuk menjaga kelestarian hutan adat tersebut.

Di dalam tradisi tersebut, kawasan hutan adat sanagt disakralkan sehingga terdapat aturan-aturan yang disepakati bersama oleh masyarakat, lembaga adat dan lembaga-lembaga lainnya untuk selalu menjaga kelestarian hutan tersebut, dan bersama-sama bertanggung jawab untuk tidak merusak kawsan hutan adat tersebut dengan alasan apapun. Dan tentunya peraturan ini berlaku bagi seluruh masyarakat karena sudah menjadi kesepakatn bersama oleh para pemangku, pemerintah setempat dan lembaga-lembaga terkait lainnya.

Tentunya pelaksanaan aturan dan tradisi ini masih terus dilakukan dengan tujuan untuk mempertahankan nilai kearifan lokal daerah tersebut, apalagi kawasan hutan tersebut dianggap memiliki nilai historis tertentu oleh para pemangku adat sehingga sangat dilindungi dengan tujuan untuk menjaga tradisi dan nilai yang sduah ada sejak dulu.

Sejauh ini nilai dan tradisi yang masih dipegang teguh oleh masyarakat menjadi nilai tersendiri bagi daerah tersebut. Sehingga hal itulah yang kemudian menjadikannya daerah wisata, dengan kekayaan tradisi menjadi nilai tambah untuk menarik wisatawan datang berkunjung, apalagi saat ini kawasan wisata yang ada di Taman Gunung Rinjani sedang dikembangkan besar-besaran menjadi salah satu geopark dunia, dan tentunya kawasan Bayan terutama daerah karang bajo yang merupakan daerah sekitaran dan perbatasan Taman Nasional Gunung Rinjani secara tidak langsung akan mengalami dampak yang signifikan dari perubahan dan kemajuan wisata tersebut

\section{Kontrol sosial}

Kontrol sosial yang berlaku dalam masyarakat dilaksanakan oleh seluruh masyarakat setempat, dengan kata lain seluruh masyarakat disini berperan dalam melakukan kontrol sosial terhadap masyarakat lainnya yang melakukan pelanggaran terhadap aturan yang sudah disepakati bersama yaitu bertanggung jawab untuk menjaga kawasan hutan adat bersama-sama dan tidak merusaknya atau memanfaatkannya tanpa persetujuan tertentu. 
Dalam hal ini lembaga adat, lembaga formal ataupun informal lainnya saling bekerja sama untuk melakukan kontrol sosial di masyarakat yang masih memiliki kesadaran rendah dengan melakukan penebangan liar sembarangan di kawasan hutan yang sudah dilindungi. Hukuman atau sanksi yang diberikan bagi masyarakat yang menebang pohong dalam kawasan hutan yang dilindungi adalah diwajibakan untuk mengeluarkan atau membeli satu ekor kerbau, kemudian beras dan bumbu-bumbu lainnya. Dan sanksi ini sudah menadi kesepakatan bersama dan dilakukan oleh masyarakat setempat secara turun temurun. Dan hingga saat ini sanksi atau hukuman yang sudah ada tersebut, mampu membuat masyarakat memiliki kesadaran tersendiri, sehingga tidak berani melakukan penebangan pohon. Bisa dikatakan sanksi yang diterapkan ini bisa dapat berjalan dengan efektif.

\section{Tipe Kepemimpinan}

Tipe kepemimpinan di dalam masyarakat, terutama dalam kelompok lembaga adat adalah orang-orang tertentu, biasanya adalah seorang pemangku adat, ataupun keturunan-keturunanya. Sehingga masyarakat biasa tidak memiliki peluang utnuk menjadi pemimpin. Karena biasanaya yang menjadi pemimpin adalah orangorang yang memiliki keturunan dengan leluhur atau pemangku adat sebelumnya, biasanya keturunan adat ini berasal dari keturunan "Lokak Pande" dan "wali bumi".

Pemimpin adat inilah yang nantinya berhak menentukan dan mengambil keputusan yang berkaitan dengan nilai atau tradisi yang berlaku dalam masyarakat setempat, terutama dalam menjaga dan memelihara pelestarian dan pengelolaan kawasan hutan adat yang sangat disakralkan hingga saat ini. Kondisi masyarakat setempat, masih memegang teguh adat istiadat yang berlaku di masyarakat dengan selalu menerapkan tradisi dan melakukan ritual-ritual yang dijarkan leluhur.

Nilai tradisi yang maish kuat inilah yang menadikan darah ini menjadi kawasan hutan wisata yang dilindungi. Sehingga dapat dikatakan masyrakat setempat cenderung bersikap tertutu terhadap perubahan. Dalam hal ini adalah perubahan-perubahan yang dianggap tidak sesuai dengan tradisi atau adat yang masih meraka yakini. Masyarakat setempat sangat menjaga dan melindungi kawasan hutan adat tersebut, sehingga dengan melakukan ritual dan adat istiadat teretntu, mereka berharap agar kawasan hutan tersebut tetap terjaga kelestariannya. Dengan menjaga tradisi yang memungkinkan bagi terciptanya kelestariah hutan diharapkan dapat menjadi warisan yang terjaga kepada generasi penerus selanjutnya. 


\section{Kesimpulan}

Peran lembaga sosial kemasyarakatan dalam pengelolaan dan pemanfaatan hutan di Desa Karang Bajo terbagi dalam tiga bentuk lembaga, yakni pertama pranata adat yang berperan dalam menjaga hutan adat dengan berbagai aturan yang bersumber dari nilai-nilai kearifan lokal, kedua, lembaga penyelenggaran pariwisata adat dan budaya yang berperan dalam mempromosikan kearifan budaya lokal, kekayaan alam dan potensi desa lainnya dalam mengembangkan kawasan ekowisata, dan ketiga lembaga budidaya lebah madu, yang berperan dalam pemanfaatan ekonomis hutan dengan turut menjaga kelestarian hutan sebagai sumber pakan lebah. Pola hubungan antara lembaga sosial kemasyarakatan dalam pengelolaan dan pemanfaatan hutan dilakukan dengan sinergi multi-lembaga yang bersifat komplementer dan saling mendukung satu sama lain. Hubungan antar lembaga tersebut diikat dalam nilai-nilai solidaritas, sistem ekonomi, sistem tradisi, kontrol sosial, dan kepemimpinan.

\section{Daftar Pustaka}

Lawang, Robert. 2005. Kapital Sosial Dalam Perspektif Sosiologik. Jakarta: Fisip UI Press.

Leibo, Jefta. 1990. Sosiologi Perdesaan Yogyakarta: Andi Ofset.

Maskun, Sumitro. 1993. Pembangunan Masyarakat Desa. Yogyakarta: Media Widya.

Melissa Justine. 2013. Studi Kearifan Lokal Sasi Kelapa Pada Masyarakat Adat di Desa Ngilnof Maluku Tenggara.

Putu Gede Parma. 2014. Pengembangan Model Penguatan Lembaga Pertanian Sebagai Prime Mover Pembangunan Kawasan Daerah Penyangga Pembangunan Wisata Kintamani, Singaraja.

Rahardjo. 1999. Pengantar Sosiologi Perdesaan dan Pertanian. Yogyakarta: Gadjah Mada Universuty Press.

Saeful Bachrein. 2016. Pendekatan Desa Membangun di Jawa Barat: Strategi dan Kebijakan Pembangunan Perdesaan.

Soedjito. 1987. Aspek Sosial Budaya Dalam pembangunan Perdesaan. Yogyakarta: Tiara Wacana.

Soekanto, Soerjono. 1984. Struktur dan Proses Sosial: Suatu Pengantar Sosiologi pembangunan. Jakarta Rajawali.

Soetomo. 2009. Pembangunan Masyarakat. Yogyakarta: Pustaka Pelajar.

Usman, Sunyoto. 2012. Pembangunan dan Pemberdayaan Masyarakat. Yogyakarta: Pustaka Pelajar.

Yamani. 2011. Perlindungan Hutan Berbasis Hukum Lokal di Enam Komunitas Adat, Bengkulu. 